Gut, 1975, 16, 887-893

\title{
Effect of urogastrone on gastric secretion and plasma gastrin levels in normal subjects
}

\author{
J. B. EldER, P. C. GANGUli, I. E. GILlESPIE, E. L. GERRING, AND \\ H. GREGORY \\ From the University Department of Surgery, Royal Infirmary, Manchester, and Research Department, I.C.I. \\ Ltd., Pharmaceuticals Division, Alderley Park, Cheshire
}

SUMMARY Purified human urogastrone was given by intravenous infusion to 12 normal volunteer subjects and measurements made of gastric acid, pepsin and intrinsic factor secretion, and of plasma gastrin concentration. Clinical, haematological, and biochemical screening tests were made throughout the period of study. Urogastrone inhibited acid and intrinsic factor secretion whether stimulated by pentagastrin, histamine, or insulin, but had a much less marked effect on gastric pepsin output. Plasma gastrin levels did not alter significantly. Limited dose-response studies showed that $0.25 \mu \mathrm{g}$ urogastrone $\mathrm{kg}^{-1} \mathrm{hr}^{-1}$ resulted in inhibition of acid output of $80 \%$ and was not associated with clinical side-effects. No significant alteration in any of the haematological or biochemical measurements was observed in any of the subjects.

The existence in human urine of an inhibitor of gastric secretion termed urogastrone has been known for many years (Gray et al., 1940a, b; Gray et al., 1942; Wick et al., 1949; Huff et al., 1950; Friedman, 1951; Gregory, 1955). Recent work has resulted in the isolation of small amounts of highly purified material (Gregory and Willshire, 1974). The two main components are polypeptides of 52 and 53 amino acid residues. The structures are the same, apart from the one additional amino acid. To provide sufficient material for evaluation in man, it was necessary to use a urogastrone preparation containing both peptides.

This paper reports our initial experience of the effect of urogastrone on gastric acid, pepsin and intrinsic factor secretion, and plasma gastrin concentration using pentagastrin, histamine, and insulin as stimulants.

\section{Methods}

VOLUNTEERS

Twelve normal male subjects aged 26 to 42 years, and weighing $61-78 \mathrm{~kg}$ were studied. Each subject gave informed consent and received one dose of urogastrone on one occasion. After an overnight fast, the resting gastric secretion was aspirated by

Received for publication 24 July 1975. continuous suction at $5-10 \mathrm{~cm} \mathrm{Hg}$ subatmospheric pressure by a nasogastric tube placed in the pyloric antrum. Three indwelling plastic cannulae were inserted into suitable forearm veins. One cannula was kept patent by filling it with $1 \mathrm{ml}$ heparinized saline solution (10,000 IU heparin/litre), and the remaining two by slow infusion of 0.154 molar sodium chloride. Throughout the study all the infusions were made using $0 \cdot 154$ molar sodium chloride at a constant rate of $27 \mathrm{ml} \mathrm{hr}^{-1}$, the concentration of any additives to the saline vehicle being adjusted accordingly.

CLINICAL AND LABORATORY MEASUREMENTS Axillary skin temperature was measured using a thermocouple taped to the skin. Gastric juice collections, recordings of skin temperature, radial pulse rate, and blood pressure were made at 15 minute intervals. Subjective comments on any discomfort noted by each volunteer before, during, and after urogastrone infusion were noted, as were general clinical observations of skin colour, sweating, or restlessness. In all subjects venous blood samples were withdrawn before and immediately after the urogastrone infusion, at the end of the test, and again 24 hours later, for estimations of haemoglobin, white blood count, ESR, platelet count, liver function tests, SGOT, SGPT, and urea and electrolyte concentrations. Aliquots of gastric juice were titrated with $0 \cdot 1 \mathrm{~N} \mathrm{NaOH}$ to the endpoint of phenol 
red (pH 6.8-8.4), and both acid concentration and output were calculated. Samples were assayed for pepsin concentration using a modified nephelometric method, and pepsin output calculated (Gerring and Allen, 1969).

PRELIMINARY DOSE RESPONSE STUDIES USING PENTAGASTRIN STIMULATION

After a basal period of one hour, each of the first six volunteers received pentagastrin $0.2 \mu \mathrm{g} \mathrm{kg}^{-1}$ $\mathrm{hr}^{-1}$ intravenously as a submaximal stimulus to gastric secretion. Urogastrone infusion was started in the other arm 60-90 minutes after the start of pentagastrin infusion, and the doses of urogastrone used were $0.125,0.25$ and $0.5 \mu \mathrm{g} \mathrm{kg}^{-1} \mathrm{hr}^{-1}$, each dose being administered once to two volunteers. At the time of the infusion, subjects were not aware of the dose of urogastrone being given or when it was being administered. In all studies infusion of the stimulant continued for 90 minutes after the end of the one-hour infusion of urogastrone. After clearing the heparinized cannula, venous blood was withdrawn on three occasions during the basal period, and at the beginning of the pentagastrin infusion, and also one hour later. Further blood samples were collected at the beginning of urogastrone infusion, then at $5,10,15,20,30,45,60$, $75,90,105$, and 120 minutes. All blood samples after separation by centrifugation were stored at $-20^{\circ} \mathrm{C}$ for up to four weeks and assayed for plasma gastrin concentration by a radioimmunoassay method (Ganguli and Hunter, 1972), the results being expressed in picograms per $\mathrm{ml}$.

A further six subjects were then studied in a similar manner with $0.25 \mu \mathrm{g}$ urogastrone $\mathrm{kg}^{-1} \mathrm{hr}^{-1}$ for one hour, using pentagastrin $0.2 \mu \mathrm{g} \mathrm{kg}^{-1} \mathrm{hr}^{-1}$ (two subjects), histamine acid phosphate $10 \mu \mathrm{g}$ $\mathrm{kg}^{-1} \mathrm{hr}^{-1}$ (two subjects), soluble insulin (BP) $0 \cdot 2$ units $\mathrm{kg}^{-1}$ intravenously (two subjects) as stimulants, and, in these, in addition to the above measurements, estimations were made of intrinsic factor concentration by the radiocobalt method of Ardeman and Chanarin (1963). One hundred milligrams mepyramine maleate was given intramuscularly 30 minutes before the histamine infusion. In the insulin studies a one hour basal period preceded the rapid intravenous injection of insulin, which was followed by collections of venous blood and of gastric juice samples at 15 minute intervals for 120 minutes. On a separate day, the test was repeated using a one hour infusion of urogastrone $0.25 \mu \mathrm{g}$ $\mathrm{kg}^{-1} \mathrm{hr}^{-1}$ intravenously which began synchronously with the insulin injection. Blood glucose concentration was measured before, 30 and 45 minutes after insulin injection, and the level decreased to less than $\mathbf{4 0} \mathrm{mg}$ per $100 \mathrm{ml}$ in each test after insulin.

\section{CALCULATION OF RESULTS}

To allow comparison of results between subjects, and in an attempt to assess uniformly the effect of different doses of urogastrone, all results were expressed as percentages of control values for each individual to the stimulant alone. In the pentagastrin and histamine studies $100 \%$ represented the mean 15 minute value of the measurement during the hour preceding urogastrone infusion. For the two subjects given insulin and urogastrone $100 \%$ represented the peak 15 minute response after insulin injection alone.

\section{Results}

PENTAGASTRIN STIMULATION

Acid Figure 1 shows mean reductions in acid output in the first six volunteers of $60 \%, 85 \%$, and $90 \%$ respectively for $0.125,0.25$, and $0.5 \mu \mathrm{g}$ urogastrone $\mathbf{~ k g}^{-1} \mathrm{hr}^{-1}$. Reductions in both acid volume and concentration were noted (Fig. 2). Acid output remained well below pre-urogastrone infusion levels for 60 to 90 minutes after the end of the infusion of the inhibitor. However, although the trend in acid output was towards control values after cessation of urogastrone infusion, no rebound in acid secretion was seen.

Pepsin Mean pepsin concentration decreased during urogastrone infusion but increased sharply 30 minutes after the end of the infusion (Fig. 3). However, examination of the pepsin outputs (Fig. 4) showed less consistent changes. Although pepsin output in general decreased within 15 minutes of the start of urogastrone infusion, this was due mainly to a reduction in the volume of gastric juice, and after $0.25 \mu \mathrm{g}$ urogastrone $\mathrm{kg}^{-1} \mathrm{hr}^{-1}$ an increase in pepsin output of up to $170 \%$ of control values was observed.

\section{HISTAMINE AND INSULIN STIMULATION}

The inhibitory effects of urogastrone on the acid output to histamine are shown in Fig. 5. This inhibition, to $40 \%$ of the pre-infusion level, was less marked than with pentagastrin, although the pattern was generally similar. Both acid volume and concentration decreased.

After insulin a marked inhibition of acid response was noted in one subject (Fig. 6), but this effect was much less striking in the other volunteer, in whom a reduction in acid output of $30 \%$ of control values was observed (Fig. 7).

Intrinsic factor output decreased markedly after urogastrone infusion when histamine was the stimulus (Fig. 8), and the pattern of inhibition tended to follow that of acid output in the studies with insulin and pentagastrin. Intrinsic factor 


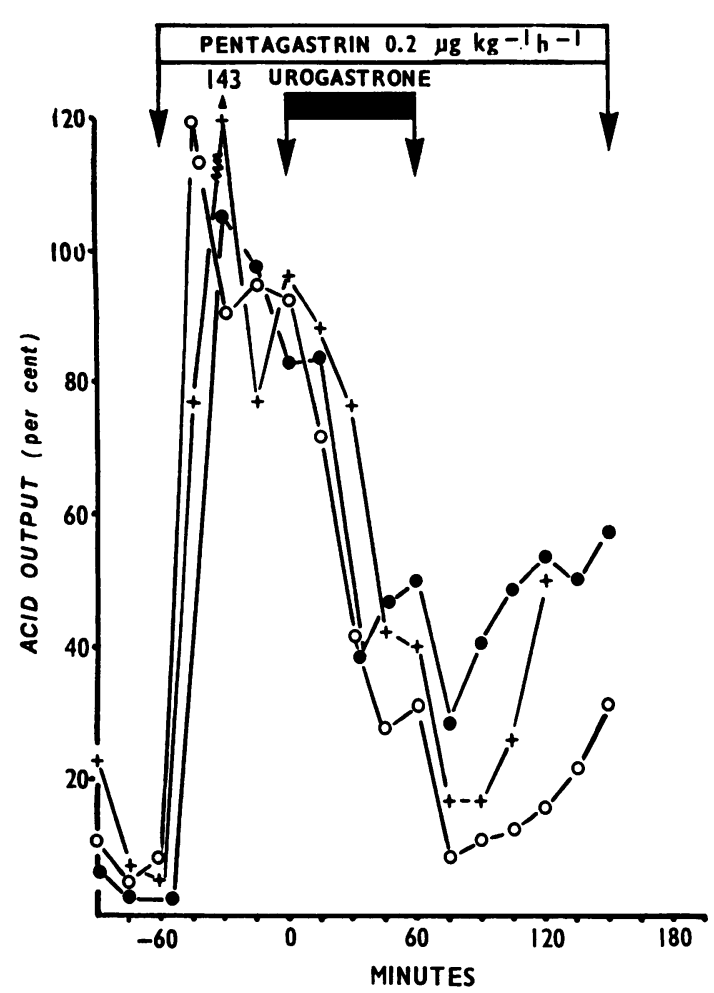

Fig. 1

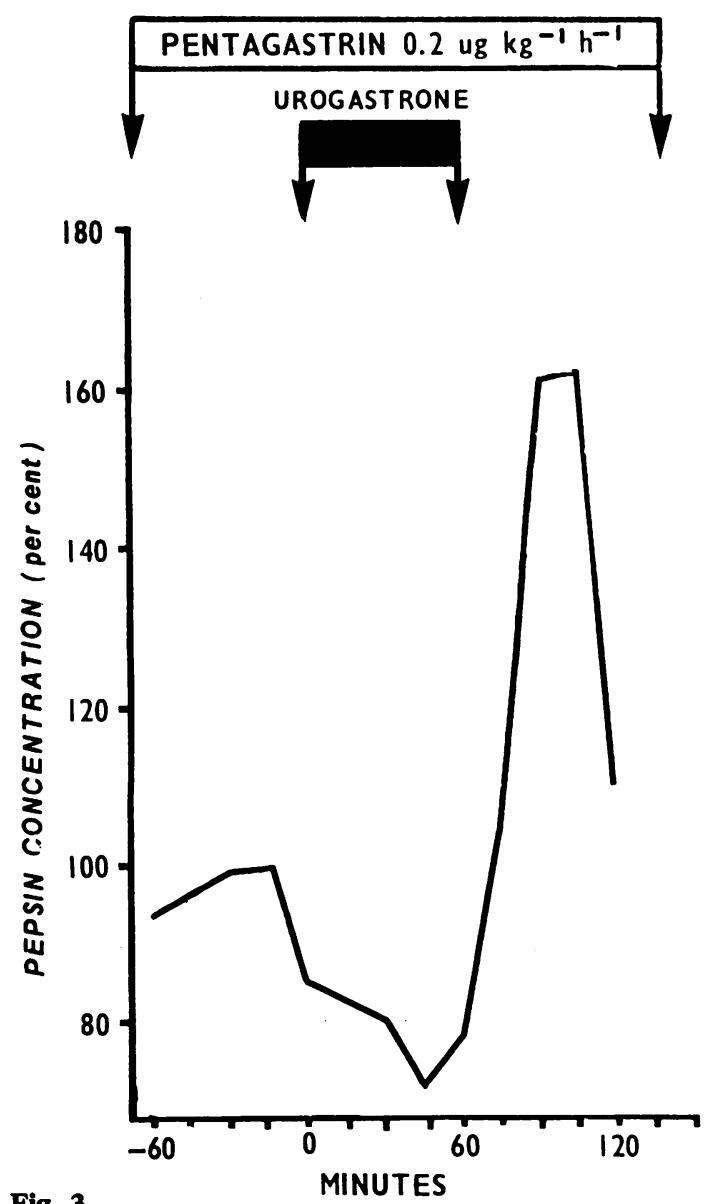

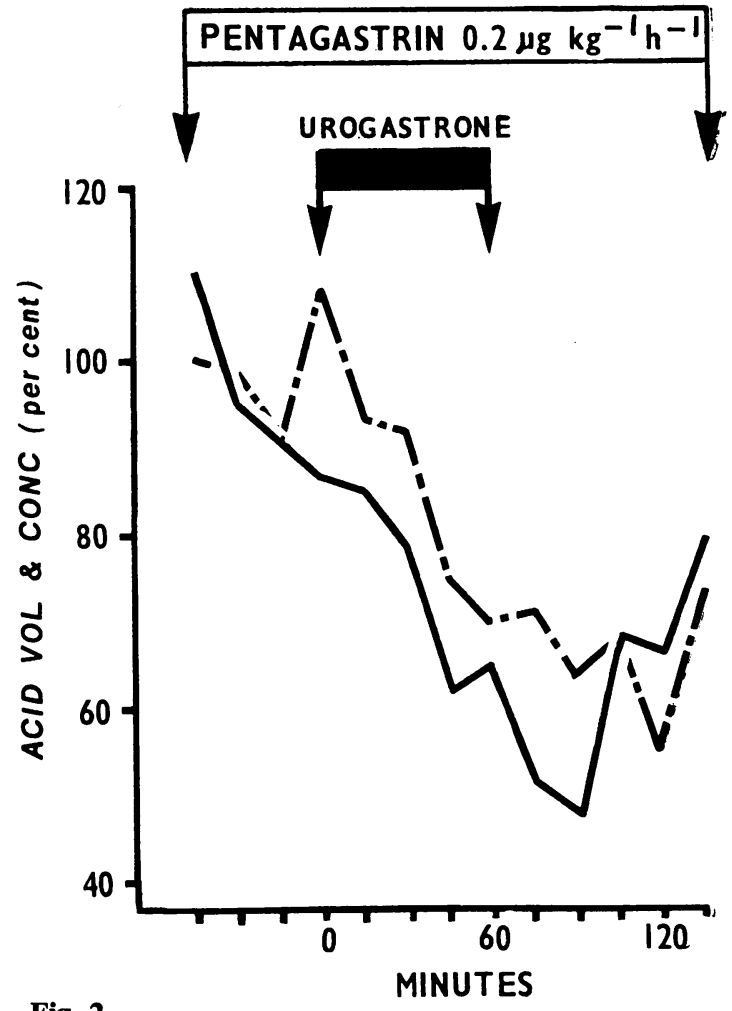

Fig. 2

Fig. 1 Inhibition of pentagastrin stimulated acid secretion by urogastrone. Each point represents the mean response of two subjects tested with one dose of urogastrone (O- 0.125 , +一+ 0.25, $\left.\bigcirc-0.5 \mu g \mathrm{~kg}^{-1} \mathrm{~h}^{-1}\right)$.

Fig. 2 Mean reduction in acid volume and concentration after urogastrone $0.25 \mu \mathrm{gg}^{-1} \mathrm{hr}^{-1}$.

Fig. 3 Mean percentage change in pepsin concentration after urogastrone. Doses of agents as in Fig. 2. 


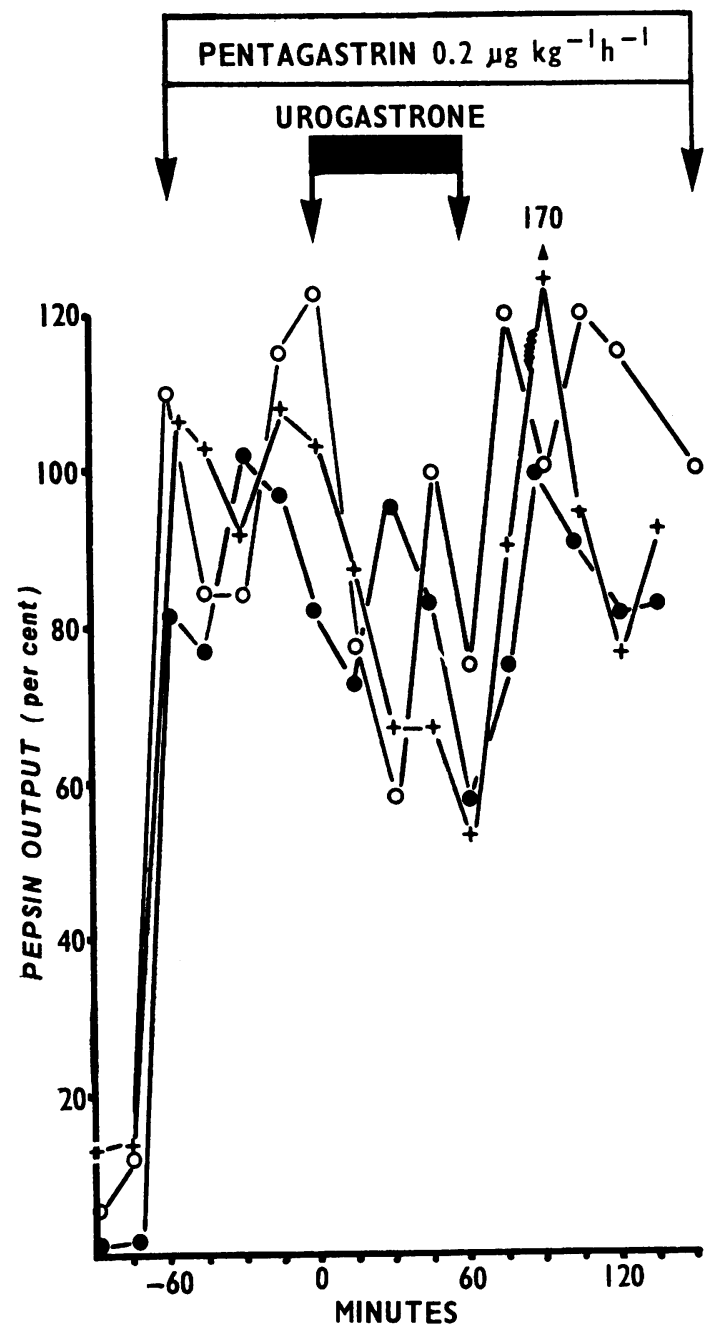

Fig. 4 Effect of urogastrone on gastric pepsin. Pepsin output as percentage of pre-urogastrone levels. (Key as in Fig. 1).

concentration decreased in each case 15 to 30 minutes after the start of the urogastrone infusion. However, no satisfactory plateau values of intrinsic factor output to submaximal pentagastrin $(0.2 \mu \mathrm{g}$ $\mathrm{kg}^{-1} \mathrm{hr}^{-1}$ ) were obtained, and histamine gave a more satisfactory plateau.

\section{PLASMA GASTRIN RESULTS}

Plasma gastrin concentrations did not alter significantly in any of the first 10 volunteers studied, before, during, or after the urogastrone infusions. In the remaining two subjects studied with insulin, urogastrone did not alter the increase in plasma gastrin concentration which followed insulin stimulation at the control test.

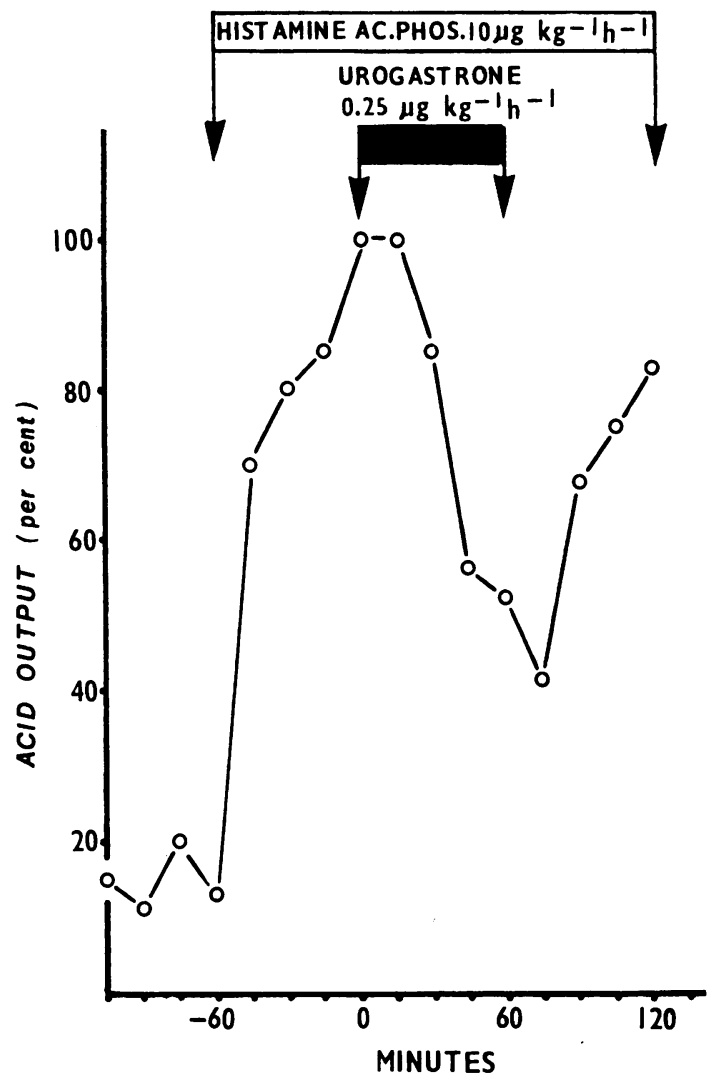

Fig. 5 Effect of urogastrone on histamine stimulated acid secretion. Mean of two tests, one in each of two subjects.

\section{CLINICAL MEASUREMENTS}

No alterations in radial pulse rate or systemic blood pressure were noted in any subject studied. After the one hour basal period a temperature decrease not exceeding $1^{\circ} \mathrm{C}$ was noted in 10 of 12 subjects, but this returned to initial values after an extra blanket was provided. No significant alterations were noted in any of the haematological or biochemical screening tests performed before, during, or after the urogastrone infusions. In two subjects, mild abdominal cramping pains were experienced when pentagastrin alone was infused, and these cramps abated shortly after the beginning of urogastrone infusion. Using $0 \cdot 125$ and $0 \cdot 25 \mu \mathrm{g}$ urogastrone $\mathrm{kg}^{-1} \mathrm{hr}^{-1}$, no clinical side-effects were noted, but both subjects receiving $0.5 \mu \mathrm{g} \mathrm{kg}^{-1} \mathrm{hr}^{-1}$ experienced fairly severe constant generalized headache within 20 to 30 minutes of initiation of the urogastrone infusion, and this persisted for up to three hours after the end of the test.

Each subject remained in excellent health at 


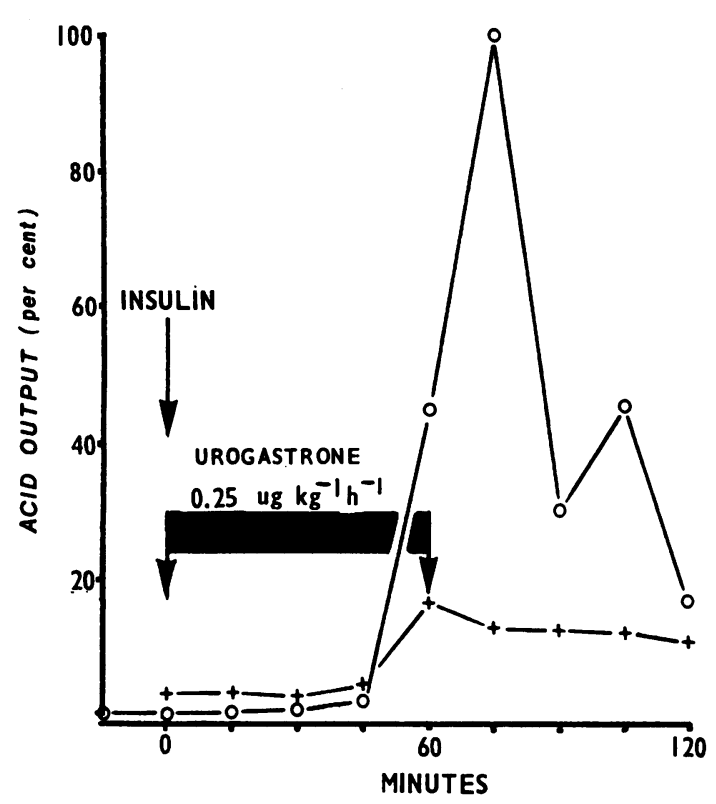

Fig. 6 Effect of urogastrone on acid output after cholinergic (insulin) stimulation. Response to insulin alone $\mathrm{O}-\mathrm{O}$, response to insulin and urogastrone +-+ .

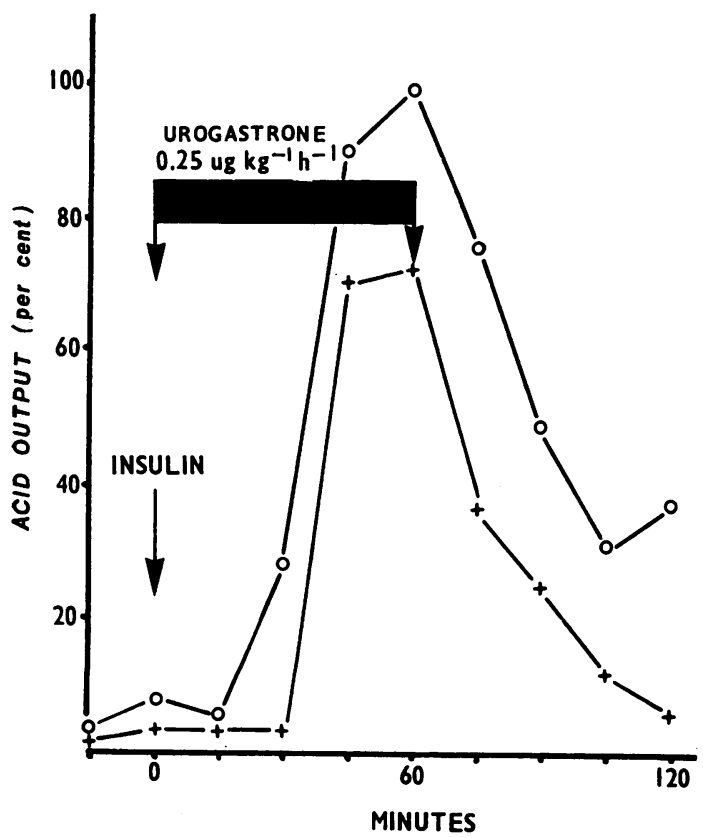

Fig. 7 Reduction in acid output to insulin with urogastrone (cf. Fig. 6).

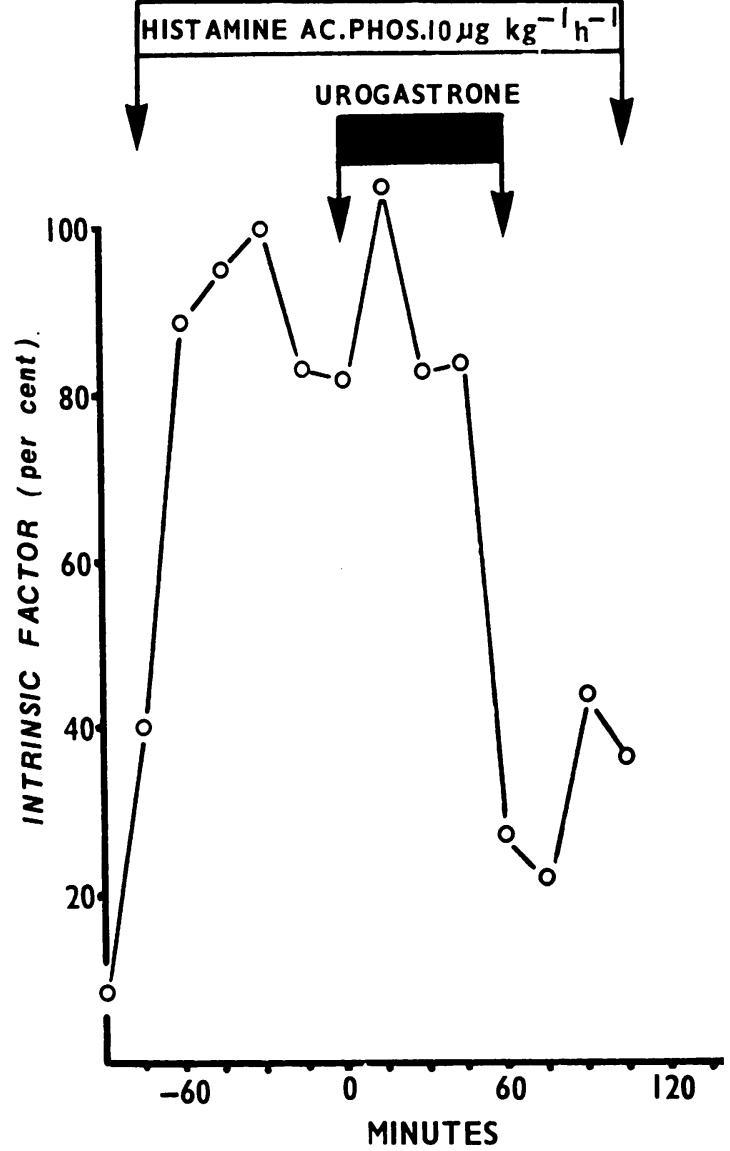

Fig. 8 Inhibition by urogastrone of intrinsic factor output to histamine.

review three to 10 months after receiving the urogastrone.

\section{Discussion}

In 1970 Gregory reported the preparation of a purer urogastrone extract, and extensive evaluation in dogs showed powerful inhibition of Heidenhain pouch responses to pentagastrin and to cholinergic stimulation, and a lesser degree of suppression of the responses to histamine (Gerring, 1970). Recently, a report of a further extract was published (Gregory and Willshire, 1974). Although individual peptide inhibitors were isolated, it was necessary to carry out the present investigations with a preparation composed of two of the closely related polypeptides. Extensive trials in dogs over periods of up to seven 
years with this material and that obtained earlier (Gregory, 1970) have revealed no untoward sideeffects.

The results now reported in man show that this urogastrone preparation is an effective inhibitor of acid secretion stimulated by exogenous submaximal pentagastrin and by histamine, and by maximally effective doses of insulin. Inhibition of acid output to pentagastrin appeared from these limited obser. vations to be dose related, but only single doses of both histamine and insulin were used in this study. There was greater variability in the case of insulin stimulation, and the quite modest inhibition seen in one of the two volunteers with insulin (Fig. 7) may have been due to the dose of insulin, $0 \cdot 2$ units $\mathrm{kg}^{-1}$, being considerably greater than the minimum required for maximal stimulation.

Both the volume and concentration of acid decreased during and after urogastrone infusions in these normal human subjects. This is in contrast to the findings of Gregory (1955) in gastric fistula dogs, and of Gerring and Haworth (1970) in Heidenhain pouch dogs stimulated by histamine, in both of which situations acid concentration was scarcely affected. However, in gastric fistula cats stimulated by pentagastrin, Gerring found that both acid concentration and volume decreased after urogastrone. Such differences may simply represent species variation, and, if so, there is clearly a greater similarity between the feline and human parietal cells in response to urogastrone, than between human and canine parietal cells.

We are unaware of previous published reports on the effect of urogastrone preparations on the secretion of intrinsic factor. In the present study, there was evidence of profound inhibition of intrinsic factor, similar in degree to that of the acid secretion, with each of the three gastric stimulants used. However, since 'plateau levels' of gastric response before starting the infusions of urogastrone were taken solely in relation to acid output, understandably the intrinsic factor 'plateaux' were much less satisfactory. Nonetheless, it is clear that intrinsic factor outputs were greatly reduced by urogastrone.

With regard to pepsin there was much less evidence of clear-cut inhibition, and, although pepsin output in general decreased within 15 minutes of the commencement of urogastrone infusion, this was due mainly to a reduction of the volume of gastric juice. The lesser degree of reduction in concentration of pepsin during urogastrone infusion was followed by a sharp increase in pepsin concentration after the end of the infusion, suggesting either an accumulation of pepsin during the infusion itself, or a true rebound stimulation.

The levels of immunoreactive plasma gastrin concentration showed no significant change either during or after the urogastrone infusions. However, this is perhaps not surprising, since exogenous stimulation of gastric secretion was used, rather than stimuli to the release of endogenous gastrin. The effects of urogastrone on basal acid and gastrin levels per se were not studied in our normal subjects.

The mechanism of action of urogastrone on gastric secretion, and its cell of origin are unknown (Fitzgerald et al., 1968). The present study suggests a specific action on the secretion of hydrogen ions, with much less effect on pepsin secretion. From studies in experimental animals, urogastrone appears to act at the parietal cell and to have a competitive action with pentagastrin and histamine (Bower, 1973; Gerring, unpublished observations). Preliminary data from our own studies on the effect of urogastrone on plasma gastrin concentrations in patients with Zollinger-Ellison syndrome further support such a mechanism (Elder et al., 1974). If this is so, the increase in pepsin concentration noted may be a reflection of this mechanism, as greater amounts of pentapeptide would then be available for stimulation of the chief cells, than would obtain before the urogastrone infusions.

The only clinical side-effect noted was headache with the largest dose of urogastrone infused-that is, $0.5 \mu \mathrm{g} \mathrm{kg}^{-1} \mathrm{hr}^{-1}$. This dose, however, was greater than that needed for inhibition of acid output of $80 \%$, a probably effective inhibition for clinical use. No significant headache or other side-effect was noted in any of the volunteers having $0.25 \mu \mathrm{g} \mathrm{kg}^{-1}$ $\mathrm{hr}^{-1}$, which from this pilot study seemed optimal for further evaluation.

If this material is to have any clinical application, it will be necessary to give multiple doses, and no repeated series have as yet been undertaken in man, in view of the slight theoretical possibility of stimulating antibodies to the polypeptide. However, this occurrence appears very unlikely in view of the size of the molecule, route of administration, and human derivation, plus the failure to demonstrate antibody formation in a large number of experimental animals subjected to many repeated doses of this and similar preparations.

We record our appreciation of the technical assistance given by Mr. I. R. Willshire with the preparation of urogastrone and thank Mrs. A. Tomlin, Staff Nurse D. Newnes, and Dr. Peter Johanson for technical assistance in performing the gastric secretion tests, Miss G. Cheetham for assistance with the gastrin assays, and the University Department of Medical Illustration, Manchester Royal Infirmary, for help with the illustrations. We also thank Dr. I. Delamore and the University Depart- 
ment of Haematology, Manchester Royal Infirmary, for performing the assays of intrinsic factor.

\section{References}

Ardeman, S., and Chanarin, I. (1963). A method for assay of human gastric intrinsic factor and for detection and titration against intrinsic factor. Lancet, 2, 1350-1354.

Bower, J. M. (1973). M.Sc. Thesis: University of Sheffield.

Elder, J. B., Ganguli, P. C., Gillespie, I. E., Delamore, I., and Gregory, H. (1974). Effect of urogastrone in ZollingerEllison syndrome. British Journal of Surgery, 61, 916.

Fitzgerald, J. D., Barrett, A. M., and Gregory, H. (1968). An attempt to define the origin of human urogastrone. In The Physiology of Gastric Secretion, p. 408-411. Edited by L. S. Semb and J. A. Myren. Universitets Forlaget: Oslo.

Friedman, M. H. F. (1951). Urinary gastric secretory depressants (urogastrone). Vitamins and Hormones, 9, 313-353.

Ganguli, P. C., and Hunter, W M. (1972). Radio-immunoassay of gastrin in human plasma. Journal of Physiology, 220, 499-510.

Gerring, E. E. L. (1970). Actions of Urogastrone. Ph.D. Thesis: University of London.

Gerring, E. L. (Unpublished observations.)
Gerring, E. L., and Allen, E. A. (1969). A nephelometric pepsin method. Clinica Chimica Acta, 24, 437-443.

Gerring, E. L., and Haworth, E. (1970). The effect of urogastrone on gastric acid secretion in dogs and cats. Rendiconti di Gastro-enterologia, 2, 167-171.

Gray, J. S., Culmer, C. U., Wieczorowski, E., and Adkinson, J. L. (1940a). Preparation of pyrogen-free urogastrone. Proceedings of the Society for Experimental Biology and Medicine, 43, 225-228.

Gray, J. S., Wieczorowski, E., and Ivy, A. C. (1940b). Inhibition of gastric secretion in man with urogastrone. American Journal of Digestive Diseases, 7, 513-515.

Gray, J. S., Wieczorowski, E., Wells, J. A., and Harris, S. C. (1942). The preparation and properties of urogastrone. Endocrinology, 30, 129-134.

Gregory, R. A. (1955). A new method for the preparation of urogastrone. Journal of Physiology, 129, 528-546.

Gregory, H. (1970). Some peptides influencing gastric-acid secretion. American Journal of Digestive Diseases, 15, 141-148.

Gregory, H., and Willshire, I. R. (1974). German Patent Publication, 2, 359, 564.

Huff, J. W., Risley, E. A., and Barnes, R. H. (1950). Preparation and properties of a purified antisecretory substance: urogastrone. Archives of Biochemistry and Biophysics, 25, 133-140.

Wick, A. N., Medz, R., and Pecka, E. F., Jr (1949). The chemical nature of urogastrone. Archives of Biochemistry and Biophysics, 24, 104-109. 